\title{
Editorial: Signal Transduction in Stomatal Guard Cells
}

\author{
Agepati S. Raghavendra ${ }^{1 *}$ and Yoshiyuki Murata ${ }^{2}$ \\ ${ }^{1}$ School of Life Sciences, University of Hyderabad, Hyderabad, India, ${ }^{2}$ Graduate School of Environmental and Life Science, \\ Okayama University, Okayama, Japan
}

Keywords: abscisic acid, cytosolic calcium, cytosolic pH, ion-channels, microbial elicitors, NO, ROS, secondary messengers

Editorial on the Research Topic

Signal Transduction in Stomatal Guard Cells

\section{INTRODUCTION}

During adaptation of plants to water stress/drought, the tiny pores on the leaf surface, called "stomata," play a very important role. Stomatal movements can modulate the entry/exit of not only $\mathrm{CO}_{2}$ /water (Lawson and Blatt, 2014) but also microbial pathogens (Agurla et al., 2014; Arnaud and Hwang, 2015). The stomatal opening/closure is brought out by changes in the turgor of guard cells. The abiotic/biotic stress factors induce a series of changes in the signaling components of guard cells, such as ROS, NO, pH and calcium, leading to efflux of ions, loss of turgor and stomatal closure. Due to their dynamic responses to signals, and the ease of handling leaf epidermis, the stomatal guard cells have been popular systems to study signal transduction in plants.

The guard cells are extremely efficient in their signal integration to optimize stomatal aperture. Murata et al. (2015) summarized the studies on signal transduction pathway in guard cells, with emphasis on downstream components. Extensive work has been carried out using the plant hormones, such as abscisic acid (ABA) and methyl jasmonate (Assmann and Jegla, 2016). Similarly, the elicitors, such as chitosan and flagellin, are also used to study sensing and transduction of signals (Agurla et al., 2014). Guard cells are unique in not only their ability to respond to external signals but also their structure and development. Very few groups are working on development and differentiation of guard cells (Chater et al., 2014; Keerthisinghe et al., 2015; Torii, 2015).

Besides the areas covered in the present research topic, there are additional aspects of contemporary interest. Some of these are: signaling by plant lipids in relation to guard cell function (Puli et al., 2016), molecular mechanisms of sensing $\mathrm{CO}_{2}$ (Engineer et al., 2016), signals from underlying mesophyll cells of leaf (Lawson et al., 2014) and cross-talk of ABA with ethylene and brassinosteroids during stomatal closure (Shi et al., 2015). Another area is the systems biology to integrate and model the signaling network in guard cells (Medeiros et al., 2015).

\section{ARTICLES IN THE RESEARCH TOPIC}

Received: 07 November 2016

Accepted: 19 January 2017

Published: 07 February 2017

Citation:

Raghavendra AS and Murata Y (2017) Editorial: Signal Transduction in Stomatal Guard Cells.

There have been several reviews on signaling components during stomatal closure, which are in different journals. The present research topic has been planned to provide a set of articles as a compendium and a ready source of information for all those interested in guard cell function.

Most of the work on signal transduction in guard cells has been with ABA and MJ, while such studies with microbial elicitors are limited. The guard cells perceive the presence of microbes though the microbe associated molecular patterns (MAMPs). The signaling events initiated by MAMPs overlap with the effects of ABA, particularly with reference to the rise in ROS, NO, 
cytosolic $\mathrm{Ca}^{2+}$ and activation of ion channels (Ye and Murata). Agurla and Raghavendra assessed the multiple signaling components induced by plant hormones or microbial elicitors. They proposed that reactive oxygen species (ROS), cytosolic free $\mathrm{Ca}^{2+}$ and ion channels are the major converging points while ROS, NO and cytosolic free $\mathrm{Ca}^{2+}$ are points of divergence. The end result is the ion channel modulation causing an efflux of $\mathrm{K}^{+} / \mathrm{Cl}^{-} /$malate from guard cells leading to stomatal closure. The major role of ROS and NO in guard cells during the stomatal closure is well established (Gayatri et al., 2013; Song et al., 2014). However, the role of $\mathrm{NO}$ is quite intriguing as $\mathrm{NO}$ can either amplify or limit (by scavenging) the effects of ROS (Laxalt et al.). Further, other gasotransmitters such as $\mathrm{H}_{2} \mathrm{~S}$ can also regulate stomatal aperture (Scuffi et al.).

Abscisic acid induces not only stomatal closure, but also integrates multiple physiological processes, including leaf senescence. Using mutants, Song et al., describe how ABA can regulate the components of senescence, namely gene expression, calcium channel activation in plasma membrane, loss of chlorophyll and ion leakage. Thus, ABA action through $\mathrm{Ca}^{2+}$ signaling appears to function during leaf senescence as well.

Protein phosphorylation is an important strategy for integrating different signals in guard cells (Zhang et al., 2014; Vilela et al., 2015). Often the signal transduction processes involve mitogen-activated protein kinases (MAPK), which and drive the cascade of events. Lee et al. highlight the advances in the MAPK-mediated guard cell signaling. These kinases mediate phosphorylation of their next target protein. Balmant et al. describe the methods to study post translational modification (PTM) and redox modification of guard cell proteins. With improved technology, further studies on PTM are bound to intensify and reveal interesting insights. For example, reactive carbonyl species function downstream of ROS production in abscisic acid signaling in guard cells (Islam et al., 2016). Similarly, the 14-3-3 proteins could target and modify different proteins in guard cells (Cotelle and Leonhardt).

The role of guard cell sugars in the stomatal movement is acknowledged, but detailed studies are lacking. Using citrus plants with over-expressed hexokinase I in the guard cells,

\section{REFERENCES}

Agurla, S., Gayatri, G., and Raghavendra, A. S. (2014). Nitric oxide as a secondary messenger during stomatal closure as a part of plant immunity response against pathogens. Nitric Oxide 43, 89-96. doi: 10.1016/j.niox.2014.07.004

Arnaud, D., and Hwang, I. (2015). A sophisticated network of signaling pathways regulates stomatal defenses to bacterial pathogens. Mol. Plant. 8, 566-581. doi: 10.1016/j.molp.2014.10.012

Assmann, S. M., and Jegla, T. (2016). Guard cell sensory systems: recent insights on stomatal responses to light, abscisic acid, and $\mathrm{CO}_{2}$. Curr. Opin. Plant Biol. 33, 157-167. doi: 10.1016/j.pbi.2016.07.003

Chater, C. C., Oliver, J., Casson, S., and Gray, J. E. (2014). Putting the brakes on: abscisic acid as a central environmental regulator of stomatal development. New Phytol. 202, 376-391. doi: 10.1111/nph.12713

Engineer, C. B., Hashimoto-Sugimoto, M., Negi, J., Israelsson-Nordström, M., Azoulay-Shemer, T., Rappel, W. J., et al. (2016). $\mathrm{CO}_{2}$ sensing and $\mathrm{CO}_{2}$ regulation of stomatal conductance: advances and open questions. Trends Plant Sci. 21, 16-30. doi: 10.1016/j.tplants.2015.08.014
Lugassi et al. provide a convincing study that hexokinase regulates photosynthesis and promotes stomatal closure in not only annual species, but also in perennials. The description of an optimized procedure for the isolation of abaxial epidermal peels from grasses, including barley, wheat and Brachypodium, to study their responses to $\mathrm{ABA}$ and $\mathrm{CO}_{2}$ (Shen et al.), would open up an exciting range of possibilities.

\section{CONCLUDING REMARKS}

The articles in our research topic provide interesting leads for future work. The stomatal guard cells are excellent models to study PTM of proteins by ROS as well as NO during signal transduction. Such PTM studies could explain the interactions of 14-3-3 proteins with MAP kinases in guard cells. Hexoses can contribute to the guard cell osmoticum, but their origin from within guard cells or mesophyll cells needs to be investigated. A rise in ROS, NO and cytosolic $\mathrm{pH}$ of guard cells is essential for stomatal closure, but their exact sequence and their interactions are quite interesting for further studies. The signaling events initiated by MAMPs are fairly understood, but the identity of MAMP-receptors is to be established.

\section{AUTHOR CONTRIBUTIONS}

$\mathrm{AR}$ and $\mathrm{YM}$ assessed the information in the Frontiers articles, as well as the available literature. Both AR and YM drafted and finalized the manuscript together.

\section{ACKNOWLEDGMENTS}

We thank all the authors who responded to our invitation and contributed to this Special Research Topic. The work on stomatal guard cells in the lab of $\mathrm{AR}$ is supported by grants from JC Bose National Fellowship (No. SR/S2/JCB06/2006) from the Department of Science and Technology and another from Department of Biotechnology (No. BT/PR9227/PBD/16/748/2007), both in New Delhi.

Gayatri, G., Agurla, S., and Raghavendra, A. S. (2013). Nitric oxide in guard cells as an important secondary messenger during stomatal closure. Front. Plant Sci. 4:425. doi: 10.3389/fpls.2013.00425

Islam, M., Ye, W., Matsushima, D., Munemasa, S., Okuma, E., Nakamura, Y., et al. (2016). Reactive carbonyl species mediate abscisic acid signaling in guard cells. Plant Cell Physiol. 57, 2552-2563. doi: 10.1093/pcp/pcw166

Keerthisinghe, S., Nadeau, J. A., Lucas, J. R., Nakagawa, T., and Sack, F. D. (2015). The Arabidopsis leucine-rich repeat receptor-like kinase MUSTACHES enforces stomatal bilateral symmetry in Arabidopsis. Plant J. 81, 684-694. doi: $10.1111 /$ tpj.12757

Lawson, T., and Blatt, M. R. (2014). Stomatal size, speed, and responsiveness impact on photosynthesis and water use efficiency. Plant Physiol. 164, 1556-1570. doi: 10.1104/pp.114.237107

Lawson, T., Simkin, A. J., Kelly, G., and Granot, D. (2014). Mesophyll photosynthesis and guard cell metabolism impacts on stomatal behaviour. New Phytol. 203, 1064-1081. doi: 10.1111/nph.12945

Medeiros, D. B., Daloso, D. M., Fernie, A. R., Nikoloski, Z., and Araújo, W. L. (2015). Utilizing systems biology to unravel stomatal function and the 
hierarchies underpinning its control. Plant Cell Environ. 38, 1457-1470. doi: $10.1111 /$ pce. 12517

Murata, Y., Mori, I. C., and Munemasa, S. (2015). Diverse stomatal signaling and the signal integration mechanism. Annu. Rev. Plant Biol. 66, 369-392. doi: 10.1146/annurev-arplant-043014-114707

Puli, M. R., Rajsheel, P., Aswani, V., Agurla, S., Kuchitsu, K., and Raghavendra, A. S. (2016). Stomatal closure induced by phytosphingosine-1-phosphate and sphingosine-1-phosphate depends on nitric oxide and $\mathrm{pH}$ of guard cells in Pisum sativum. Planta 244, 831-841. doi: 10.1007/s00425-016-2545-Z

Shi, C., Qi, C., Ren, H., Huang, A., Hei, S., and She, X. (2015). Ethylene mediates brassinosteroid-induced stomatal closure via $\mathrm{G} \alpha$ protein-activated hydrogen peroxide and nitric oxide production in Arabidopsis. Plant J. 82, 280-301. doi: $10.1111 /$ tpj.12815

Song, Y., Miao, Y., and Song, C. P. (2014). Behind the scenes: the roles of reactive oxygen species in guard cells. New Phytol. 201, 1121-1140. doi: $10.1111 /$ nph. 12565

Torii, K. U. (2015). Stomatal differentiation: the beginning and the end. Curr. Opin. Plant Biol. 28, 16-22. doi: 10.1016/j.pbi.2015.08.005
Vilela, B., Pagès, M., and Riera, M. (2015). Emerging roles of protein kinase CK2 in abscisic acid signaling. Front. Plant Sci. 6:966. doi: 10.3389/fpls.2015. 00966

Zhang, T., Chen, S., and Harmon, A. C. (2014). Protein phosphorylation in stomatal movement. Plant Signa. Behav. 9:e972845. doi: 10.4161/ 15592316.2014 .972845

Conflict of Interest Statement: The authors declare that the research was conducted in the absence of any commercial or financial relationships that could be construed as a potential conflict of interest.

Copyright (c) 2017 Raghavendra and Murata. This is an open-access article distributed under the terms of the Creative Commons Attribution License (CC $B Y)$. The use, distribution or reproduction in other forums is permitted, provided the original author(s) or licensor are credited and that the original publication in this journal is cited, in accordance with accepted academic practice. No use, distribution or reproduction is permitted which does not comply with these terms. 